\title{
PERBANDINGAN KEUNTUNGAN DENGAN SISTEM BAGI HASIL PADA USAHA GARAM RAKYAT DI KABUPATEN PAMEKASAN, JAWA TIMUR
}

\section{Comparison of Profit at Different Sharecropping System in Traditional Salt Production in Pamekasan Regency, East Java}

\author{
"Campina Illa Prihantini', Yusman Syaukat ${ }^{2}$ dan Anna Fariyanti ${ }^{2}$ \\ ${ }^{1}$ Sekolah Tinggi IImu Ekonomi (STIE) Bakti Bangsa Pamekasan, Indonesia \\ 2Institut Pertanian Bogor, Indonesia \\ Diterima tanggal: 6 Februari 2017 Diterima setelah perbaikan: 20 April 2017 \\ Disetujui terbit: 6 Juni 2017 \\ "email: camps.world.smaga@gmail.com
}

\begin{abstract}
ABSTRAK
Salah satu indikator ketidakefisienan usaha pertanian yang dijalankan dengan sistem bagi hasil adalah adanya perbedaan keuntungan yang diterima oleh masing-masing pihak yang diterima oleh kedua belah pihak. Tujuan utama dari penelitian ini adalah menganalisis keuntungan yang diterima oleh pihak yang terlibat dalam sistem bagi hasil usaha garam rakat. Pihak-pihak yang terlibat dalam sistem bagi hasil usaha garam rakyat adalah pemilik lahan dan petani penggarap. Lokasi penelitian adalah tiga kecamatan di Kabupaten Pamekasan. Metode penelitian yang dilakukan adalah analisis keuntungan usaha tani, kemudian membandingkan tingkat keuntungan antara pemilik lahan dan petani penggarap untuk setiap pola bagi hasil. Hasil perbandingan keuntungan yang diterima oleh masing-masing pihak disebut nilai keuntungan relatif $(\mu)$. Metode penentuan responden yang digunakan adalah purposive dan snowballing sampling. Hasil analisis menunjukkan bahwa terdapat perbedaan keutungan yang diterima oleh pemilik lahan dan petani penggarap. Nilai keuntungan relatif $(\mu)$ yang dihasilkan menunjukkan bahwa nilai tersebut masih belum sesuai dengan yang diharapkan. Kesimpulan akhir dari penelitian ini adalah bahwamemang terdapat ketidakefiisienan dalam usaha garam rakyat yang dijalankan dengan sistem bagi hasil di Kabupaten Pamekasan.
\end{abstract}

Kata Kunci: Perbandingan keuntungan, sistem bagi hasil, usaha garam rakyat

\begin{abstract}
One of inefficient indicators in agricultural busineess with sharing system is the difference of profit get by each participant. The main objective of this research is to identify profit accepted by the participants in salt production business. Stakeholders in salt production busineess with profit sharing system are landlord and salt farmer. Research location is in Pamekasan regency. This research used profit analysis, then the value of their profit is comparing each other for every type of sharing system in this regency. The value of comparation's profit is called rellative profit value $(\mu)$. Respondents selected by using purposive and snowballing sampling. The result showed that there area signifficant difference of profit accepted by the landlord and the salt farmer. The result of rellative profit value $(\mu)$ does not match with this research hypothesis. The final conclusion of this research is salt production business with profit sharing system in Pamekasan regency is inefficient.
\end{abstract}

Keywords: profit comparison, profit sharing system, salt production business

\section{PENDAHULUAN}

Salah satu tujuan yang hendak dicapai dalam kegiatan usaha tani adalah menerima imbalan yang sesuai dengan korbanan yang telah dilakukan, termasuk usaha gram rakyat. Usaha garam rakyat di Kabupaten Pamekasan pada umumnya dilaksanakan dengan sistem bagi hasil. Data yang diterima dari Sekretariat Daerah Kabupaten (Sekdakab) Pamekasan (2015) menyebutkan bahwa jumlah petani garam yang tergabung dalam sistem bagi hasil mencapai angka 1.031 orang atau sekitar 70,47 persen dari total petani garam yang ada di kabupaten ini. Menurut Scheltema (1985). sistem bagi hasil dapat dibedakan menjadi beberapa pola. Ada pola bagi dua, pola bagi tiga, 
pola bagi empat, bahkan terdapat usaha tani yang dijalankan dengan sistem bagi lima. Pola bagi hasil di Kabupaten Pamekasan yang umum dijalankan ada dua, yakni pola bagi dua (1:1) dan pola bagi tiga (2:1). Pola bagi dua adalah ketika pemilik lahan dan petani penggarap menerima bagian yang sama besar (perbandingan keuntungan yang diterima adalah 1:1). Pola bagi tiga terjadi jika perbandingan keuntungan yang diterima oleh pemilik lahan dan petani penggarap adalah $2: 1$. Perbedaan pola ini ternyata memengaruhi hak dan kewajiban masingmasing pelaku bagi hasil. Selain itu, pola bagi hasil secara tidak langsung memengaruhi tingkat keuntungan yang diterima oleh petani penggarap dan pemilik lahan, selaku dua pelaku utama sistem bagi hasil. Tingkat keuntungan yang diterima oleh masing-masing pelaku bagi hasil dapat digunakan sebagai indikator dalam menentukan efisiensi sistem bagi hasil (Ray, 1999; Roy and Serfes, 2001).

$\begin{array}{ccccc}\text { Sukesi } & (2011) & \text { menyebutkan } & \text { bahwa } \\ \text { permasalahan } & \text { utama yang dihadapi } & \text { petani } \\ \text { garam dalam usaha garam rakyat adalah }\end{array}$
pemasaran dan pembiayaan. Petani garam harus menghadapi saluran pemasaran yang relatif pendek (Rochwulaningsih, 2013, Prihantini, 2015). Saluran pemasaran yang pendek menggambarkan saluran pemasaran yang efisien (Asmarantaka, 2012). Namun, saluran pemasaran yang pendek dapat mengindikasikan bahwa terdapat beberapa lembaga pemasaran yang dominan dan cenderung menguasai saluran pemasaran tersebut. Dalam sistem bagi hasil, pemasaran garam hasil produksi cenderung dikuasai oleh pemilik lahan, yang juga berperan sebagai pedagang besar dan tengkulak (Rochwulaningsih, 2013). Kontrak yang dijalani petani penggarap dan pemilik lahan dapat dikatakan cenderung menguntungkan pemilik lahan. Berikut beberapa contoh nyata dalam praktik bagi hasil di lapang (a) penentuan harga beli garam secara sepihak, dilakukan oleh pemilik lahan, (b) harga beli garam relatif lebih rendah dari harga yang telah ditetapkan oleh pemerintah, (c) seluruh hasil produksi harus dijual kepada pemilik lahan. Tiga poin tersebut menunjukkan ketidakadilan dalam sistem bagi hasil.

Permasalahan lainnya adalah pembiayaan atau permodalan. Petani garam yang menjalankan usaha garam dengan lahan sendiri atau lahan sewa mungkin tidak mengalami kesulitan dalam mengakses modal produksi. Berbeda dengan keduanya, petani garam yang menjalankan usaha garam rakyat dengan sistem bagi hasil cenderung menghadapi kendala pembiayaan. Petani garam yang terlibat dalam sistem bagi hasil pada umumnya adalah petani dengan kondisi ekonomi menengah ke bawah (Scheltema, 1985; Lole, 1995; Nurdiani, 2013; Rochwulaningsih, 2013) dan memiliki keterbatasan dalam mengakses kredit formal (Bardhan and Rudara, 1978; Braverman, 1984; Azriani, 2014). Bukti nyata kendala pembiayaan yang dihadapi petani penggarap misalnya (a) pinjaman tanpa bunga, bunga diterapkan secara tidak langsung (Prihantini et al., 2016), (b) perbedaan harga beli garam dalam kegiatan jual-beli garam adalah metode untuk penentuan bunga tidak langsung (Basu, 1997), (c) suku bunga tidak langsung justru lebih besar nilainya dari suku bunga pinjaman formal (Basu, 1997; Anggraini, 2015; Prihantini et al., 2016).

Penelitian mengenai usaha garam yang dijalankan dengan sistem bagi hasil belum banyak dilakukan. Terlebih, penelitian inifokus dalam analisis usaha tani dalam dua pola bagi hasil, yakni pola bagi dua dan pola bagi tiga. Tujuan dari penelitian ini adalah menganalisis perbedaan keuntungan yang diterima oleh pemilik lahan dan petani penggarap. Perbandingan keuntungan dalam setiap pola dapat menghasilkan kesimpulan pola manakah yang lebih berkeadilan dan lebih efisien dalam usaha garam rakyat di Kabupaten Pamekasan. Hasil penelitian ini diharapkan dapat digunakan sebagai bahan rekomendasi untuk pengembangan usaha garam di Kabupaten Pamekasan pada khususnya dan usaha pegaraman nasional pada umumnya.

\section{METODOLOGI}

Penelitian ini memilih lokasi di tiga kecamatan di Kabupaten Pamekasan, yakni Kecamatan Tlanakan, Kecamatan Galis, dan Kecamatan Pademawu. Tiga kecamatan tersebut dipilih sebagai lokasi penelitian karena daerah tersebut merupakan produsen garam terbesar di Kabupaten Pamekasan (Sekretariat Daerah Kabupaten Pamekasan, 2016). Penelitian ini dirasa penting dilakukan untuk melihat pengaruh sistem bagi hasil dalam usaha garam rakyat terhadap keuntungan yang diterima oleh masing-masing pihak yang terlibat di Kabupaten Pamekasan.

Data yang dikumpulkan terdiri atas data primer dan data sekunder. Pengumpulan data primer dilaksanakan selama dua bulan, yakni bulan Maret hingga April 2016. Data primer 
diperoleh melalui wawancara langsung kepada responden. Jawaban pertanyaan dicatat dalam kuesioner yang telah disiapkan oleh peneliti. Data sekunder merupakan informasi mengenai usaha garam, jumlah produksi garam, luas lahan garam, dan hal-hal yang berkaitan dengan pegaraman nasional. Data sekunder diperoleh dari berbagai media dan sumber, seperti dari Dinas Perikanan dan Kelautan Kabupaten Pamekasan, Badan Pusat Statistik Kabupaten Pamekasan, Sekretariat Daerah Kabupaten Pamekasan, website resmi Kementerian Kelautan dan Perikanan, website resmi Badan Pusat Statistik, dan beberapa jurnal online lainnya.

Responden yang terpilih dalam mencari data primer dalam penelitian ini dipilih dengan menggunakan metode purposive dan snowballing sampling. Metode purposive digunakan untuk memilih responden secara sengaja dan snowballing dilakukan dengan cara bergilir. Penggunaan metode ini dirasa paling tepat karena ketersediaan data spesifik mengenai petani garam yang terlibat dalam bagi hasil sangatlah terbatas. Setelah dilakukan analisis, jumlah responden yang dapat digunakan adalah 115 orang, terdiri atas 22 orang pemilik lahan dan 93 orang petani penggarap. Petani penggarap terbagi menjadi dua kelompok, yakni 13 orang tergabung dalam pola bagi dua dan 80 orang tergabung dalam pola bagi tiga. Jumlah responden tersebut diharapkan telah mampu menyebar normal dan telah mewakili (representatif) kondisi lapang.

Metode analisis yang digunakan dalam penelitian ini adalah analisis keuntungan dalam usaha tani. Usaha tani adalah ilmu yang mempelajari bagaimana seseorang mengalokasikan sumberdaya yang ada secara efektif dan efisien untuk memperolehkeuntungan yang tinggi pada waktu tertentu (Soekartawi, 1986). Salah satu indikator keberhasilan dalam melakukan suatu usaha tani adalah adanya peningkatan pendapatan petani. Analisis pendapatan usaha tani membutuhkan dua keterangan pokok, yakni keadaan penerimaan dan keadaan pengeluaran selama usaha tani tersebut dijalankan dalam waktu yang tidak dapat ditetapkan. Soeharjo dan Patong (1973) menjelaskan bahwa analisis usaha tani dapat digunakan untuk dua tujuan, yakni (1) menggambarkan keadaan sekarang dari suatu kegiatan usaha tani dan (2) menggambarkan keadaan yang akan datang dari perencanaan atau tindakan yang telah atau akan dilakukan.
Analisis tersebut digunakan untuk mengestimasi keuntungan yang diterima oleh pemilik lahan dan petani penggarap dalam sistem bagi hasil usaha garam rakyat di Kabupaten Pamekasan. Perhitungan analisis keuntungan dilakukan dengan menggunakan Microsoft Excel dan analisis uji beda dilakukan dengan menggunakan program aplikasi Minitab 11.0.

\section{Analisis Keuntungan Sistem Bagi Hasil}

Analisis ini digunakan untuk melihat bagaimana sistem bagi hasil yang selama ini berjalan dalam usaha garam rakyat di Kabupaten Pamekasan. Adanya berbagai pola dalam sistem bagi hasil di Kabupaten Pamekasan menarik untuk diteliti dan dikaji lebih lanjut. Dengan membandingkan nilai keuntungan petani penggarap terhadap pemilik lahan, nantinya dapat dilihat pola sistem bagi hasil manakah yang paling baik dan paling efisien. Nilai keuntungan yang diperoleh dari masing-masing pihak tentu dipengaruhi oleh beberapa variabel, yakni besarnya bagi hasil, harga garam, jumlah produksi garam, total biaya produksi (total biaya input tetap dan total biaya input variabel) yang dikeluarkan oleh masingmasing, dan penerimaan dari biaya pinjaman yang ditanggung oleh petani penggarap. Variabel besarnya bagi hasil yang digunakan dalam analisis ini berbeda-beda disesuaikan dengan kondisi di lapangan yang terdapat pola bagi hasil juga beragam. Pola bagi hasil yang umum dilakukan di Kabupaten Pamekasan adalah pola bagi dua dan pola bagi tiga. Variabel lainnya, yakni harga garam, jumlah produksi garam, biaya produksi garam akan diproksi dengan nilai rata-rata dari keseluruhan.

Penerimaan yang diterima oleh petani penggarap dipengaruhi oleh besarnya bagi hasil yang diterimanya, harga dan jumlah output yang diterimanya. Nilai keuntungan yang diterima oleh petani penggarap adalah besarnya nilai penerimaan dikurangi dengan biaya operasional atau biaya total variabel produksi garam, sesuai dengan persamaan (1) dan (2).

$$
\begin{aligned}
& T R_{F}=(k)^{*}\left[\left(P_{1}, Y_{1}\right)+\left(P_{2}, Y_{2}\right)+\left(P_{3}, Y_{3}\right)\right] \\
& \Pi_{F}=(k)^{\star}\left[\left(P_{1}, Y_{1}\right)+\left(P_{2}, Y_{2}\right)+\left(P_{3}, Y_{3}\right)\right]-(k)^{*} T V C \ldots
\end{aligned}
$$

Sementara itu, pemilik lahan, bagian yang diterima dipengaruhi oleh besarnya bagi hasil yang diterimanya, harga dan jumlah output yang diterimanya. Nilai keuntungan yang diterima oleh pemilik lahan dipengaruhi oleh besar penerimaanya, 
biaya total tetap, dan penerimaan dari pinjaman (kredit) yang secara langsung dipengaruhi oleh biaya pinjaman yang ditanggung oleh petani penggarap sesuai dengan persamaan (3) dan (4).

$$
\begin{aligned}
& T R_{L}=(1-k)^{*}\left[\left(\begin{array}{ll}
P_{1} & Y_{1}
\end{array}\right)+\left(\begin{array}{ll}
P_{2} & Y_{2}
\end{array}\right)+\left(P_{3} Y_{3}\right)\right] \\
& \pi_{L}=(1-k)^{*}\left[\left(P_{1} Y_{1}\right)+\left(P_{2} Y_{2}\right)+\left(P_{3} Y_{3}\right)\right]-(1-k)^{*}(\text { TFC }) \\
& (1-k)^{*}(T V C)+(1-k)^{*}\left(C O F^{*} K R D T\right)
\end{aligned}
$$

\section{Dimana/ Where :}

$\mathrm{TR}_{\mathrm{F}}=$ Penerimaan total petani penggarap (Rupiah)/ Sharecropper's total revenue (IDR)

$\mathrm{TR}_{\mathrm{L}} \quad=$ Penerimaan tota pemilik lahan (Rupiah)/ Landlord's total revenue (IDR)

$\pi_{\mathrm{F}} \quad=$ Keuntungan yang diterima oleh petani penggarap (Rupiah)/ Sharecropper's profit (IDR)

$\Pi_{\mathrm{L}} \quad=$ Keuntungan yang diterima oleh pemilik lahan (Rupiah)/ Landlord's profit (IDR)

$\mathrm{k}=$ Koefisien besarnya bagi hasil, $\mathrm{k}=\frac{1}{2} \mathrm{dan} \frac{1}{3}$ ${ }_{1}^{1}$ Coefficient of sharecropping system, $k \stackrel{3}{=}$ $\frac{1}{2}$ and $\frac{1}{3} \mathrm{~s}$

$\mathrm{P}_{1}=$ Harga garam Kualitas Produksi $(\mathrm{KP}) 1$ Non-Pinjaman (Rupiah per ton)/ Price of first production quality non-credit (IDR per ton)

$\mathrm{P}_{2}=$ Harga garam Kualitas Produksi $(\mathrm{KP}) 2$ Non-Pinjaman (Rupiah per ton)/ Price of second production quality non-credit (IDR per ton)

$\mathrm{P}_{3} \quad=$ Harga garam Kualitas Produksi $(\mathrm{KP}) 3$ Non-Pinjaman (Rupiah per ton)/ Price of third production quality non-credit (IDR per ton)

$\mathrm{Y}_{1} \quad=$ Jumlah garam Kualitas Produksi (KP) 1 (ton)/ Total production of first quality (ton)

$\mathrm{Y}_{2} \quad=$ Jumlah garam Kualitas Produksi (KP) 2 (ton)/ Total production of second quality (ton)

$\mathrm{Y}_{3} \quad=$ Jumlah garam Kualitas Produksi (KP) 3 (ton)/ Total production of third quality (ton)

TVC = Besarnya biaya total input variabel (Rupiah)/ Total variable input cost (IDR)

TFC = Besarnya biaya total input tetap (Rupiah)/ Total fixed input cost (IDR)

$\mathrm{COF}=$ Besarnya biaya modal pinjaman (persen) $/$ Cost of fund (percent)

$\mathrm{KRDT}=$ Besarnya pinjaman (kredit) yang diberikan (Rupiah)/ Credit given to the sharecropper (IDR)
Selanjutnya, $\pi_{F}$ dan $\pi_{L}$ akan dibandingkan hingga menghasilkan suatu angka tertentu, yakni nilai keuntungan relatif. Sesuai dengan persamaan berikut:

$$
\frac{\pi F}{\pi L}=\mu
$$

Dimana/ Where:

$\mu=$ Nilai keuntungan relatif $/$ Value of relative profit

Nilai $\mu$ yang diharapkan adalah/ The expected value of $\mu$ is $0<\mu<1$

Nilai perbandingan keuntungan relatif ini akan menunjukkan apakah bagi hasil dengan pola tersebut sudah berkeadilan ataukah belum. Kemudian angka-angka tersebut akan dibandingkan untuk setiap pola. Nilai perbandingan dapat dijadikan sebagai salah satu indikator bahwa bagi hasil dengan pola tersebut telah berkeadilan. Selain itu, indikator lainnya yang akan dibahas dalam analisis ini adalah mengenai hak dan kewajiban masing-masing pihak. Analisis ini akan dijelaskan secara deskriptif.

\section{HASIL DAN PEMBAHASAN}

Sistem bagi hasil merupakan sistem pertanian yang tidak efisien (Marshall, 1920). Terdapat banyak hal yang menyebabkan sistem ini menjadi tidak efisien. Salah satunya adalah terdapat ketidakadilan antara pemilik lahan dan petani penggarap. Salah satu indikator yang digunakan adalah perbedaan tingkat keuntungan yang diterima oleh masing-masing pihak. Beberapa penelitian menyebutkan bahwa sistem bagi hasil kurang memberikan keadilan kepada petani penggarap. Lole (1995) dan Nurdiani (2013) menyimpulkan dalam penelitiannya di Kawasan Timor Barat dan Kabupaten Sumenep bahwa keuntungan yang diterima oleh pemilik lahan lebih besar daripada petani penggarap. Uji beda dan koefisien perbandingan keuntungan relatif yang telah dilakukan dalam analisis ini merupakan bukti nyata bahwa memang terdapat ketidakadilan dalam pola bagi hasil usaha garam rakyat di Kabupaten Pamekasan.

\section{Struktur Keuntungan yang Diterima dalam Pola Bagi Tiga}

Pembahasan kali ini menjelaskan struktur keuntungan yang diterima oleh masing-masing pihak yang terlibat dalam suatu pola bagi hasil, lebih tepatnya adalah pola bagi tiga. Berdasarkan 
teori pendapatan usaha tani, keuntungan usaha tani merupakan hasil pengurangan antara total penerimaan terhadap total pengeluaran yang dikeluarkan. Penerimaan dalam usaha garam rakyat merupakan penerimaan dari penjualan garam yang terdiri atas tiga kualitas produksi $(\mathrm{KP})$, yakni KP 1, KP 2, dan KP 3. Masing-masing kualitas produksi memiliki harga yang berbeda. Struktur biaya dalam usaha garam rakyat terbagi menjadi dua, yakni biaya input tetap dan biaya input variabel. Biaya input tetap merupakan penyusutan atas input-input yang digunakan, seperti sedong, kincir air, sorkot, pencacah, baumeter, dan sebagainya. Biaya input variabel dalam usaha garam rakyat merupakan biaya yang dikeluarkan untuk input yang jumlahnya ditentukan oleh jumlah garam produksi yang dihasilkan, seperti biaya tenaga kerja, biaya solar, dan biaya karung. Penerimaan atas bagi hasil merupakan nilai dari penjualan garam yang telah dikurangi dengan biaya transportasi dan marjin pemasaran. Biaya transportasi dan marjin pemasaran akan dimasukkan ke dalam struktur keuntungan pemilik lahan. Pembagian keuntungan atas bagi hasil didasarkan pada pola bagi hasil yang telah disepakati sebelumnya. Setelah itu, terdapat pembagian keuntungan antara pemilik lahan dan petani penggarap. Pemilik lahan menerima penerimaan dari biaya pinjaman sedangkan petani penggarap tidak menerimanya. Struktur keuntungan yang diterima oleh masing-masing pihak disajikan dalam Tabel 1 dan Tabel 2.

Rata-rata penerimaan atas bagi hasil yang diterima oleh pemilik lahan terdiri atas tiga bagian, yakni atas bagi hasil, atas marjin atau keuntungan pemasaran, dan atas biaya pinjaman. Penerimaan atas bagi hasil setelah menerima dua bagian adalah sebesar Rp 34.506.000 per musim per hektar. Penerimaan atas marjin pemasaran yang diterima oleh pemilik lahan adalah Rp 462.716 per musim per hektar. Penerimaan atas biaya pinjaman adalah sebesar Rp 1.056.218 per musim per hektar.

Total penerimaan yang diterima oleh pemilik lahan adalah sebesar Rp 36.024.934 per hektar per musim. Penerimaan atas bagi hasil diperoleh dengan mengurangi penerimaan atas penjualan garam terhadap biaya atau ongkos pemasaran yang dikeluarkan oleh pemilik lahan. Pada struktur biaya pemasaran, pemilik lahan telah memasukkan keuntungan atas pemasaran yang dilakukannya. Nilai marjin tersebut memberikan kontribusi sekitar 1,28 persen, sedangkan sumber penerimaan utama dari pemilik lahan adalah usaha garam yang mencapai 95,78 persen. Penerimaan atas biaya tanggungan pinjaman yang ditanggung petani penggarap adalah sebesar Rp 1.056.218. Penerimaan tersebut memberikan kontribusi sebesar 2,94 persen terhadap total penerimaan pemilik lahan. Rata-rata total pengeluaran pemilik lahan adalah sebesar Rp 5.632.069 per musim per hektar, terdiri atas biaya transportasi yang dikeluarkan untuk memasarkan garam atau menjual garam ke perusahaan garam, penyusutan input tetap, dan biaya input variabel yakni solar dengan perbandingan 1:1 terhadap petani penggarap. Pengeluaran terbesar yang dikeluarkan oleh pemilik lahan ternyata ditujukan untuk biaya transportasi dan penyusutan input yang masing-masing mencapai angka 43,29\% dan 42,07\% terhadap total pengeluaran pemilik lahan. Sementara itu, biaya input variabel solar hanya menyumbang sekitar $14,64 \%$ terhadap total pengeluaran. Hasil analisis menyebutkan rata-rata keuntungan yang diterima oleh pemilik lahan adalah sebesar Rp 30.392.865 per musim per hektar. Rata-rata penerimaan atas bagi hasil yang diterima oleh petani penggarap hanya bersumber dari usaha garam rakyat yang dijalankan. Rata-rata penerimaan atas bagi hasil adalah sebesar Rp 17.253.000 per musim per hektar. Nilai ini merupakan satu bagian yang diterima oleh petani penggarap, sedangkan pemilik lahan menerima dua bagian ( Rp 36.024.934 per musim per hektar). Pengeluaran petani penggarap terdiri atas biaya input variabel, yakni tenaga kerja, karung, dan solar, dan biaya atas pinjaman. Biaya solar merupakan biaya yang telah dibagi dua dengan pemilik lahan. Biaya input variabel solar memberikan kontribusi sebesar 32,05\% terhadap total pengeluaran petani penggarap. Pengeluaran terbesar petani penggarap justru digunakan untuk menanggung biaya atas pinjaman yang diterimanya, yaitu sebesar Rp 1.056.218 per hektar per musim. Biaya tersebut memberikan kontribusi sebesar $41,04 \%$ terhadap total pengeluaran petani penggarap. Rata-rata biaya yang dikeluarkan oleh petani penggarap adalah sebesar Rp 2.572.647 per musim per hektar. Dengan demikian, rata-rata keuntungan yang diterima petani penggarap adalah Rp 14.680.353 per musim per hektar.

Berdasarkan analisis keuntungan, terdapat hubungan yang erat antara pinjaman dan keuntungan yang diterima oleh masing-masing pihak yang terlibat dalam usaha garam dengan sistem bagi hasil. Keterkaitan antara pinjaman dan keuntungan ditentukan oleh besarnya biaya pinjaman. 
Tabel 1. Struktur Rata-rata Keuntungan yang diterima oleh Pemilik Lahan dan Petani Penggarap dalam Pola Bagi Tiga (Rupiah/Ha/Musim) di Kabupaten Pamekasan, 2016.

Table 1. Structure of Profit Average Accepted by the Landlord and the Sharecropper in 2:1 Sharecropping System (IDR/Ha/Season) in Pamekasan Regency, 2016.

\begin{tabular}{|c|c|c|c|c|c|}
\hline & \multirow[t]{2}{*}{ Struktur/Structure } & \multicolumn{2}{|c|}{ Pemilik Lahan/ Landlord } & \multicolumn{2}{|c|}{$\begin{array}{l}\text { Petani Penggarap/ } \\
\text { Sharecropper }\end{array}$} \\
\hline & & $\mathbf{R p}$ & $\%$ & IDR & $\%$ \\
\hline \multirow[t]{5}{*}{ (1) } & Penerimaan / Revenue & & & & \\
\hline & $\begin{array}{l}\text { (a) Penerimaan atas Bagi Hasil/ } \\
\text { Revenue from Sharecropping }\end{array}$ & $34,506,000$ & 95.78 & $17,253,000$ & 100.00 \\
\hline & $\begin{array}{l}\text { (b) Penerimaan atas Marjin Pemasaran/ } \\
\text { Revenue from Marketing Margin }\end{array}$ & 462,716 & 1.28 & 0 & 0.00 \\
\hline & $\begin{array}{l}\text { (c) Penerimaan atas Biaya Pinjaman/ } \\
\text { Revenue from Cost of Fund }\end{array}$ & $1,056,218$ & 2.94 & 0 & 0.00 \\
\hline & Total Penerimaan / Total Revenue & $36,024,934$ & 100.00 & $17,253,000$ & 100.00 \\
\hline \multirow[t]{10}{*}{ (2) } & Pengeluaran / Cost & & & & \\
\hline & $\begin{array}{l}\text { (a) Biaya Transportasi/Transportation } \\
\text { Cost }\end{array}$ & $2,438,625$ & 43.29 & 0 & 0.00 \\
\hline & $\begin{array}{l}\text { (b) Penyusutan Input Tetap/Fixed Input } \\
\text { Shrinkage }\end{array}$ & $2,369,179$ & 42.07 & 0 & 0.00 \\
\hline & (c) Biaya Input Variabel/Input Variable & & & & \\
\hline & Cost & 0 & 0.00 & 254,367 & 9.89 \\
\hline & Tenaga Kerja/Labor & 0 & 0.00 & 437,797 & 17.02 \\
\hline & Karung/Sack & 824,265 & 14.64 & 824,265 & 32.05 \\
\hline & Solar/Diesel Fuel & & & & \\
\hline & Biaya Pinjaman / Cost of Fund & 0 & 0 & $1,056,218$ & 41.04 \\
\hline & Total Pengeluaran / Total Cost & $5,632,069$ & 100.00 & $1,513,428$ & 100.00 \\
\hline (3) & Keuntungan / Profit & $30,392,865$ & 100.00 & $15,388,717$ & 100.00 \\
\hline
\end{tabular}

Sumber: Data Primer 2016/Source:Field Survey 2016

Bagi petani penggarap, biaya tanggungan atas pinjaman yang diterimanya akan dimasukkan sebagai struktur pengeluaran. Biaya pinjaman ini tentu tidak disadari oleh petani penggarap. Berbeda dengan petani penggarap, biaya pinjaman menjadi struktur penerimaan bagi pemilik lahan. Besarnya biaya pinjaman terhadap keuntungan petani penggarap adalah $7,19 \%$, sedangkan besarnya biaya pinjaman terhadap keuntungan pemilik lahan adalah $3,48 \%$. Jika kita bandingkan kedua nilai tersebut, maka terdapat suatu kesimpulan. Kesimpulan tersebut adalah bahwa biaya pinjaman ternyata memberikan kontribusi yang lebih besar bagi petani penggarap daripada terhadap pemilik lahan. Pemilik lahan cenderung mengabaikan atas biaya pinjaman tersebut karena hanya memiliki persentase sebesar 3,48. Berbeda dengan petani penggarap, nilai biaya pinjaman tersebut relatif besar, yakni sebesar $7,19 \%$, sehingga dapat dikatakan bahwa biaya pinjaman yang ditanggungnya memberikan pengaruh terhadap keuntungan yang diterimanya. Terlebih jika berdasarkan analisis keuntungan dalam
Tabel 1 menunjukkan besarnya kontribusi biaya pinjaman terhadap penerimaan pemilik lahan dan kontribusi biaya pinjaman terhadap biaya petani penggarap. Pemilik lahan hanya menerima 2,94\% atas biaya pinjaman sedangkan petani penggarap harus mengeluarkan biaya pinjaman sebesar $41,04 \%$. Perbandingan disini dapat dijadikan dasar bahwa tingginya biaya pinjaman tidak dapat dianggap sebagai hal sepele dalam usaha garam rakyat yang dijalankan dengan sistem bagi hasil. Perbedaan pandangan terhadap biaya pinjaman dapat dijadikan sebagai indikator bahwa terdapat ketidakadilan dalam sistem bagi hasil usaha garam rakyat di Kabupaten Pamekasan. Biaya atas pinjaman yang ditanggung petani penggarap dapat menurunkan tingkat kesejahteraan. Pemerintah perlu memikirkan kebijakan yang lebih berpihak kepada petani penggarap, terlebih dalam masalah pembiayaan. Salah satu solusi yang ditawarkan dalam kajian yang dilakukan oleh Gupta (1989) adalah memberikan subsidi kredit. Subdisi kredit ini diharapkan dapat meningkatkan kesejahteraan petani penggarap yang terlibat dalam sistem bagi hasil. 


\section{Struktur Keuntungan yang Diterima dalam Pola Bagi Dua}

Pola bagi dua juga memiliki struktur keuntungan yang sama dengan pola bagi tiga. Perbedaan keduanya terletak pada bagian yang diterima oleh masing-masing pihak yang terlibat dalam pola ini, yakni 1:1. Artinya, pemilik lahan dan petani penggarap masing-masing menerima 1 bagian. Struktur keuntungan yang diterima oleh masing-masing pihak dalam pola bagi dua disajikan dalam Tabel 2.

Struktur penerimaan pemilik lahan terdiri atas tiga sumber, yakni atas bagi hasil, atas marjin atau keuntungan pemasaran, dan atas biaya pinjaman. Rata-rata penerimaan atas bagi dua adalah sebesar Rp 17.738.307.500 per hektar per musim. Rata-rata penerimaan atas marjin pemasaran yang dilakukan olehnya adalah sebesar Rp 327.076 per hektar per musim. Rata-rata penerimaan atas biaya pinjaman adalah sebesar Rp 743.924 per hektar per musim. Sehingga total penerimaan yang diperoleh adalah sebesar Rp 18.809.307 per hektar per musim. Berdasarkan kontribusi terhadap penerimaan, penerimaan atas usaha garam memberikan nilai kontribusi terbesar, yakni $94,31 \%$, sedangkan penerimaan atas marjin pemasaran hanya sekitar $1,85 \%$. Kontribusi penerimaan atas biaya pinjaman adalah sebesar $3,95 \%$. Total pengeluaran pemilik lahan pola bagi dua tidak berbeda dengan pola bagi tiga. Struktur pengeluaran pemilik lahan terdiri atas tiga sumber, yakni biaya transportasi, penyusutan input tetap, dan biaya input variabel solar. Rata-rata total pengeluaran pemilik lahan untuk biaya transportasi adalah sebesar Rp 1.17.153 per hektar per musim. Nilai penyusutan input tetap adalah sebesar Rp 1.859.585 per hektar per musim. Biaya solar yang ditanggung oleh pemilik lahan adalah sebesar Rp. 630.057 per hektar per musim, sehingga total pengeluaran pemilik lahan adalah Rp. 4.206.795 per hektar per musim. Berdasarkan kontribusi pengeluaran terhadap total pengeluaran pemilik lahan, penyusutan input tetap memberikan kontribusi terbesar, yakni $44,20 \%$. Biaya transportasi memberikan kontribusi sebesar $40,82 \%$ dan biaya solar sekitar $14,98 \%$. Dengan demikian, rata-rata keuntungan pemilik lahan pola dua adalah sebesar Rp 14.602.512 per hektar per musim.

Tabel 2. Struktur Rata-rata Keuntungan yang Diterima oleh Pemilik Lahan dan Petani Penggarap dalam Pola Bagi Dua (Rupiah/Ha/Musim) di Kabupaten Pamekasan, 2016.

Table 2. Structure of Profit Average Accepted by the Landlord and the Sharecropper in 1:1 Sharecropping System (IDR/Ha/Season) in Pamekasan Regency, 2016.

\begin{tabular}{|c|c|c|c|c|c|}
\hline & \multirow[t]{2}{*}{ Struktur/Structure } & \multicolumn{2}{|c|}{ Pemilik Lahan/ Landlord } & \multicolumn{2}{|c|}{$\begin{array}{l}\text { Petani Penggarap/ } \\
\text { Sharecropper }\end{array}$} \\
\hline & & $\mathbf{R p}$ & $\%$ & IDR & $\%$ \\
\hline \multirow[t]{5}{*}{$(1)$} & Penerimaan / Revenue & & & & \\
\hline & $\begin{array}{l}\text { (a) Penerimaan atas Bagi Hasil/Revenue from } \\
\text { Sharecropping }\end{array}$ & $17,738,307$ & 94.31 & $17,738,307$ & 100.00 \\
\hline & $\begin{array}{l}\text { (b) Penerimaan atas Marjin Pemasaran/ } \\
\text { Revenue from Marketing Margin }\end{array}$ & 327,076 & 1.74 & 0 & 0.00 \\
\hline & $\begin{array}{l}\text { (c) Penerimaan atas Biaya Pinjaman/ Revenue } \\
\text { from Cost of Fund }\end{array}$ & 743,924 & 3.95 & 0 & 0,00 \\
\hline & Total Penerimaan / Total Revenue & $18,809,307$ & 100.00 & $17,738,307$ & 100.00 \\
\hline \multirow[t]{10}{*}{ (2) } & Pengeluaran / Cost & & & & \\
\hline & (a) Biaya Transportasi/Transportation Cost & $1,717,153$ & 40.82 & 0 & 0.00 \\
\hline & $\begin{array}{l}\text { (b) Penyusutan Input Tetap / Fixed Input } \\
\text { Shrinkage }\end{array}$ & $1,859,585$ & 44.20 & 0 & 0.00 \\
\hline & (c) Biaya Input Variabel/Variable Input & & & & \\
\hline & Cost & 0 & 0.00 & 158,846 & 2.88 \\
\hline & Tenaga Kerja/Labor & 0 & 0.00 & 312,092 & 5.66 \\
\hline & Karung/Sack & 630,057 & 14.98 & 630,057 & 11.40 \\
\hline & $\begin{array}{l}\text { Solar/Diesel Fuel } \\
\text { (d) Biaya Perbaikan Lahan / Land } \\
\text { Maintenance }\end{array}$ & 0 & 0.00 & $3,675,000$ & 66.58 \\
\hline & (e) Biaya Pinjaman / Cost of Fund & 0 & 0.00 & 743,924 & 13.48 \\
\hline & Total Biaya / Total Cost & $4,206,795$ & 100.00 & $4,775,996$ & 100.00 \\
\hline (3) & Keuntungan / Profit & $14,602,512$ & 100.00 & $12,218,388$ & 100.00 \\
\hline
\end{tabular}

Sumber: Data Primer 2016/Source:Field Survey 2016 
Rata-rata keuntungan yang diterima oleh petani penggarap pola bagi dua bersumber utama dari usaha garam rakyat yang dijalankannya. Rata-rata penerimaan yang diperolehnya adalah Rp 17.738.307 per hektar per musim. Nilai ini sama besarnya dengan nilai yang diterima oleh pemilik lahan karena perbandingan bagi hasil keduanya adalah 1:1. Total pengeluaran petani penggarap pola bagi dua ditambah dengan biaya perbaikan lahan. Hal ini disebabkan karena lahan pada pola bagi dua bersifat mudah bocor atau lahan baru yang membutuhkan perawatan ekstra yang berdampak terhadap biaya yang harus dikeluarkan. Rata-rata biaya perbaikan lahan adalah sebesar Rp 3.675.000 per hektar per musim dengan kontribusi sebesar $66,58 \%$ terhadap total pengeluaran petani penggarap. Rata-rata biaya pinjaman yang ditanggung petani penggarap adalah sebesar Rp 743.924 atau sekitar $13,48 \%$ terhadap total pengeluaran petani penggarap. Rata-rata total pengeluaran petani penggarap adalah sebesar Rp 5.519.919 per hektar per musim. Biaya perbaikan lahan memberikan kontribusi terbesar yang kemudian disusul dengan biaya pinjaman. Dengan demikian, rata-rata keuntungan yang diterima oleh petani penggarap pola bagi dua adalah sebesar Rp 12.218.388 per hektar per musim.

Sama halnya dengan pola bagi tiga, terdapat hubungan antara pinjaman dan keuntungan yang diterima dalam usaha garam rakyat yang dijalankan dengan sistem bagi hasil. Besarnya biaya pinjaman memengaruhi struktur keuntungan kedua belah pihak. Biaya pinjaman yang ditanggung petani penggarap adalah sebesar $6,09 \%$ dari keuntungan yang diterimanya, sedangkan bagi pemilik lahan adalah sebesar 5,09\% dari keuntungan yang diperolehnya. Berdasarkan nilai perbandingan terhadap keuntungan tersebut, diperoleh suatu kesimpulan bahwa biaya pinjaman memberikan kontribusi yang cukup nyata terhadap keuntungan yang diterima. Selain itu, berdasarkan analisis keuntungan, kontribusi biaya pinjaman terhadap total pengeluaran petani penggarap adalah sebesar $13,48 \%$, sedangkan kontribusi biaya pinjaman bagi total penerimaan pemilik lahan adalah 3,95\%. Nilai tersebut dapat dijadikan sebagai acuan bahwa biaya pinjaman merupakan hal penting bagi petani penggarap karena berpengaruh nyata terhadap tingkat keuntungan yang diterimanya. Bagi pemilik lahan, biaya pinjaman tidak terlalu berpengaruh karena biaya pinjaman hanya memberikan kontribusi sebesar $3,95 \%$ terhadap total penerimaan. Perbedaan pandangan terhadap biaya pinjaman dapat dijadikan sebagai indikator bahwa terdapat ketidakadilan dalam usaha garam rakyat yang dijalankan dengan sistem bagi hasil di Kabupaten Pamekasan. Baik pola bagi dua maupun pola bagi tiga, biaya atas pinjaman menjadi hal yang penting dalam penentuan keuntungan yang diterima petani penggarap. Hal ini memengaruhi kesejahteraan petani penggarap. Pemerintah diharapkan dapat memberikan subsidi kredit seperti yang diusulkan oleh Gupta (1989) dalam kajian yang dilakukannya. Kebijakan ini diharapkan dapat meningkatkan kesejahteraan petani penggarap untuk mengatasi masalah pembiayaan.

\section{Perbandingan Keuntungan yang diterima antar Dua Pola Bagi Hasil}

Keuntungan yang diterima oleh pemilik lahan dan petani penggarap yang menjalani suatu pola bagi hasil diduga berbeda nilainya. Rata-rata keuntungan yang diterima oleh pemilik lahan relatif lebih besar nilainya daripada yang diterima oleh petani penggarap. Besar rata-rata keuntungan yang diterima oleh masing-masing pihak yang terlibat telah diestimasi berdasarkan persamaan matematis yang telah disampaikan dalam Tabel 2. Masing-masing pihak telah berkontribusi sesuai dengan proporsi yang telah disepakati di awal perjanjian.

Berdasarkan hasil analisis yang telah dilakukan, rata-rata keuntungan yang diterima oleh petani penggarap dan pemilik lahan untuk pola bagi tiga hasil ternyata berbeda nyata, namun untuk pola bagi dua, ternyata tidak berbeda nyata. Selain itu, rata-rata keuntungan yang diterima oleh pemilik lahan pola bagi dua dan pola bagi tiga ternyata berbeda nyata, pun demikian untuk petani penggarap pola bagi dua dan pola bagi tiga ternyata juga berbeda nyata. Kesimpulan ini diperoleh dengan cara melakukan Uji beda (Two Sample T-Test and Confidence Interval) terhadap kelompok petani penggarap dan pemilik lahan. Berdasarkan Tabel 3, untuk pola bagi dua, tingkat keuntungan yang diterima oleh petani penggarap berada dalam kisaran $\mathrm{Rp}$ 5.715.150 hingga Rp 18.610.250 dengan rata-rata keuntungan sebesar Rp 12.218.388 (per hektar per musim). Tingkat keuntungan yang diterima oleh pemilik lahan berada dalam kisaran Rp 7.674.950 hingga Rp 20.896.850 dengan rata-rata tingkat keuntungan sebesar Rp 14.602 .512 (per hektar per musim). Berdasarkan hasil analisis uji beda dalam Lampiran 1 , nilai $P$-value yang diperoleh adalah sebesar 0,086 yang mana nilai tersebut lebih besar dari 
$\alpha=0,05$, sehingga kesimpulan yang dapat diambil adalah bahwa tidak terdapat perbedaan yang nyata antara rata-rata keuntungan yang diterima oleh pemilik lahan dan petani penggarap.

Tingkat keuntungan yang diterima oleh petani penggarap pola bagi tiga yang disajikan dalam Tabel 3 berada dalam kisaran Rp 7.161.100 hingga Rp 45.423.150 dengan rata-rata keuntungan sebesar Rp. 14.680.353 (per hektar per musim). Sedangkan tingkat keuntungan yang diterima oleh pemilik lahan berada dalam kisaran Rp. 14.529.900 hingga Rp 96.359.400 dengan rata-rata sebesar Rp. 30.392.865 (per hektar per musim). Uji beda yang dilakukan pada pola bagi tiga ini menyimpulkan bahwa terdapat perbedaan rata-rata keuntungan yang nyata antara petani penggarap dan pemilik lahan dalam taraf nyata lima persen. Hal ini didasarkan pada nilai $P$-value dalam Lampiran 1 yang bernilai 0,000 , yang mana nilai tersebut lebih kecil dari $\alpha=0,05$. Dengan demikian, terbukti bahwa memang terdapat perbedaan yang nyata antara pemilik lahan dan petani penggarap. Jika kita analisis, perbandingan rata-rata keuntungan yang diterima oleh pemilik lahan dan petani penggarap dalam pola bagi tiga menuju angka 2:1. Hal tersebut menunjukkan bahwa pola ini disebut sebagai pola bagi tiga.

Selain itu, berdasarkan uji beda yang dilakukan dalam Lampiran 1, menunjukkan bahwa terdapat perbedaan rata-rata keuntungan yang nyata antara pemilik lahan pola bagi dua dan pemilik lahan pola bagi tiga. Kesimpulan ini didasarkan pada nilai $P$-value sebesar 0,0000 yang lebih kecil dari $\alpha=0,05$. Dengan demikian, kesimpulan dari uji tersebut adalah bahwa terdapat perbedaan yang nyata antar pemilik lahan dari dua pola bagi hasil tersebut. Hasil uji beda yang dilakukan dalam analisis ini ternyata menunjukkan hal yang sama untuk petani penggarap. Ternyata, rata-rata keuntungan yang diterima oleh petani penggarap pola bagi dua berbeda nyata terhadap rata-rata keuntungan yang diterima oleh petani penggarap pola bagi tiga. Berdasarkan nilai $P$-value yang ditunjukkan dalam Lampiran 1, diperoleh nilai sebesar 0,05 yang lebih kecil dari $\alpha=0,05$. Jika kita analisis, perbedaan rata-rata keuntungan yang diterima oleh petani penggarap antar pola ini adalah sebesar Rp 2.551.965 per hektar per musimnya, sedangkan untuk rata-rata keuntungan pemilik lahan pola bagi dua bernilai dua kali lipat terhadap rata-rata keuntungan yang diterima oleh pemilik lahan pola bagi tiga.

Kesimpulan yang dapat diambil adalah rata-rata keuntungan dalam pola bagi dua tidak berbeda nyata, artinya masing-masing pihak yang terlibat dalam pola ini hampir menerima bagian yang sama besar, yakni 1:1. Sementara untuk pola bagi tiga, terdapat perbedaan yang nyata antara pemilik lahan dan petani penggarap. Nilai rata-rata keuntungan yang diperoleh juga menuju perbandingan 1:2. Rata-rata keuntungan yang diterima pemilik lahan relatif lebih besar daripada rata-rata keuntungan yang diterima petani penggarap. Hal ini telah sesuai dengan hasil kajian yang dilakukan oleh Nurdiani (2013). Hasil

Tabel 3. Perbandingan Perbedaan Keuntungan yang diterima untuk Setiap Pola Bagi Hasil di Kabupaten Pamekasan, 2016.

Tabel 3. Comparison of Profit Accepted for Each Sharecropping System in Pamekasan Regency, 2016.

\begin{tabular}{lccc}
\hline \multicolumn{1}{c}{$\begin{array}{c}\text { Pola Bagi Hasil/ } \\
\text { Sharecropping System }\end{array}$} & \multicolumn{2}{c}{$\begin{array}{c}\text { Keuntungan yang Diterima (Rp/Ha/Musim)/ } \\
\text { Profit Accepted (IDR/Ha/Season) }\end{array}$} \\
\cline { 2 - 4 } & $\begin{array}{c}\text { Minimum/ } \\
\text { Minimum }\end{array}$ & $\begin{array}{c}\text { Maksimum/ } \\
\text { Maximum }\end{array}$ & $\begin{array}{c}\text { Rata-rata/ } \\
\text { Average }\end{array}$ \\
\hline $\begin{array}{l}\text { Pola Bagi Dua/1:1 Sharecropping } \\
\text { System }\end{array}$ & & & \\
Pemilik Lahan / Landlord & $7,674,950$ & $20,896,850$ & $14,602,512$ \\
Petani Penggarap / Sharecropper & $5,715,150$ & $18,610,250$ & $12,218,388$ \\
\hline Pola Bagi Tiga / 2:1 Sharecropping & & & \\
System & & & \\
Pemilik Lahan / Landlord & $14,529,900$ & $96,359,400$ & $30,392,865$ \\
Petani Penggarap / Sharecropper & $7,161,100$ & $45,423,150$ & $14,680,353$ \\
\hline
\end{tabular}

Sumber: Data Primer 2016/Source:Field Survey 2016 
penelitian tersebut menunjukkan bahwa pemilik lahan cenderung menerima keuntungan yang lebih besar daripada petani penggarap. Kesimpulan lain yang dapat diambil adalah antara pola bagi dua dan pola bagi tiga ternyata lebih menguntungkan pola bagi dua kepada petani penggarap. Petani penggarap dan pemilik lahan menerima keuntungan yang sama besar. Namun, pemilik lahan biasanya akan merubah pola bagi dua menjadi pola bagi tiga. Pemilik lahan beranggapan bahwa pola bagi tiga lebih menguntungkan karena menerima bagian yang lebih besar dari petani penggarap. Zhao et al. (2006) dan Pi (2013) menjelaskan bahwa pola bagi dua hanyalah normatif. Artinya, dalam praktek di lapang tidak sepenuhnya berjalan. Pemilik lahan cenderung merubah pola bagi hasil agar lebih memberikan keuntungan kepada dirinya. Pola bagi dua dapat terus berjalan jika kesuburan tanah tetap dapat terjaga. Pemakaian pupuk secara intensif juga memengaruhi kesuburan tanah, sehingga memengaruhi pola bagi hasil. Semakin sering dilakukan pemupukan, semakin cepat pula kesuburan tanah berubah. Sehingga pola bagi hasil juga berubah.

\section{Perbandingan Nilai Keuntungan Relatif Antar Pola Bagi Hasil}

Nilai koefisien keuntungan relatif $(\mu)$ merupakan perbandingan keuntungan yang diterima oleh petani penggarap terhadap keuntungan yang diterima oleh pemilik lahan. Nilai $\mu$ yang diharapkan berada dalam rentang nilai $0<\mu<1$. Tujuan utama analisis ini adalah untuk melihat pola bagi hasil manakah yang paling memberikan keadilan kepada masing-masing pihak yang terlibat dalam pola bagi hasil tertentu. Nilai $\mu=1,00$ pada pola dua menunjukkan bahwa pola bagi ini telah memberikan keadilan, yang artinya masing-masing pihak telah menerima bagian sesuai dengan perbandingan $1: 1$. Nilai $\mu=0,50$ pada pola bagi tiga menunjukkan bahwa pola bagi ini telah berkeadilan karena masing-masing pihak telah menerima keuntungan yang sesuai dengan bagian yang telah disepakati sebelumnya.

Berdasarkan hasil analisis dan estimasi di lapang. Nilai $\mu$ pada pola bagi dua berada dalam rentang nilai 0,745 hingga 0,891 dengan nilai rata-rata $\mu$ sebesar 0,829 (Tabel 4). Nilai rata-rata $\mu=0,829$ dapat diartikan bahwa keuntungan yang diterima oleh petani penggarap sebesar 82,9 $\%$ dari keuntungan yang diterima oleh pemilik lahan. Nilai rata-rata $\mu$ tersebut dapat dikatakan masih jauh untuk menuju angka 1,000. Terdapat sekitar 0,171 untuk mencapai angka 1,000. Artinya, rata-rata keuntungan yang diterima oleh petani penggarap masih belum sama nilainya dengan rata-rata keuntungan yang diterima oleh pemilik lahan. Nilai rata-rata $\mu$ tersebut merupakan salah satu indikator dan bukti nyata bahwa pola bagi dua belum memberikan keadilan kepada petani penggarap. Hal ini juga dapat mencerminkan bahwa petani penggarap masih belum menerima bagian yang sama besarnya dengan yang diterima oleh pemilik lahan. Salah satu penyebab petani penggarap belum menerima bagian yang setimpal adalah tingginya biaya pinjaman yang harus ditanggungnya. Berdasarkan analisis pada Tabel 2, biaya pinjaman merupakan salah satu struktur pengeluaran yang kontribusinya berada diatas $10 \%$ terhadap total pengeluaran petani penggarap.

Nilai $\mu$ untuk pola bagi tiga, dalam Tabel 4 , berada dalam rentang nilai 0,463 hingga 0,508 dengan nilai rata-rata $\mu$ sebesar 0,485 . Nilai rata-rata $\mu=0,485$ dapat diartikan bahwa keuntungan yang diterima oleh petani penggarap sebesar $48,50 \%$ dari keuntungan yang diterima oleh pemilik lahan. Nilai $\mu$ mendekati nilai 0,50 , namun masih terdapat selisih sekitar 0,015 untuk

Tabel 4 Perbandingan Koefisien Keuntungan Relatif untuk Setiap Pola Bagi Hasil di Kabupaten Pamekasan, 2016.

Table 4 Comparison of Relative Profit Coefficient for Each Sharecropping System in Pamekasan Regency, 2016.

\begin{tabular}{lrrr}
\hline Pola Bagi Hasil/ & \multicolumn{3}{c}{ Nilai $\boldsymbol{\mu} / \boldsymbol{\mu}$ Value } \\
\cline { 2 - 4 } Sharecropping System & $\begin{array}{c}\text { Minimum / } \\
\text { Minimum }\end{array}$ & $\begin{array}{c}\text { Maksimum / } \\
\text { Maximum }\end{array}$ & $\begin{array}{c}\text { Rata-rata / } \\
\text { Average }\end{array}$ \\
\hline Pola Bagi Dua / 1:1 Sharecropping System & 0,745 & 0,891 & 0,829 \\
\hline Pola Bagi Tiga / 2:1 Sharecropping System & 0,463 & 0,508 & 0,485 \\
\hline
\end{tabular}

Sumber: Data Primer 2016/Source:Field Survey 2016 
menuju angka 0,50. Nilai tersebut mengindikasikan bahwa pola bagi tiga ternyata belum memberikan keadilan kepada petani penggarap. Hal ini menunjukkan bahwa petani penggarap belum menerima bagian yang sesuai dengan kesepakatan bersama, dimana petani penggarap menerima satu bagian dan pemilik lahan menerima dua bagian. Salah satu bukti nyata penyebab petani penggarap belum menerima keadilan dalam pola bagi tiga adalah biaya pinjaman yang bernilai sangat tinggi. Berdasarkan Tabel 1, kontribusi biaya pinjaman terhadap total pengeluaran petani penggarap adalah sebesar $41,04 \%$. Biaya pinjaman ini merupakan pengeluaran terbesar bagi petani penggarap. Berbeda dengan pemilik lahan, kontribusi biaya pinjaman terhadap total penerimaan pemilik lahan sekitar 2,94\%. Perbedaan pandangan antara pemilik lahan dan petani penggarap menjadi salah satu faktor penyebab ketidakdilan dalam pola bagi tiga usaha garam rakyat di Kabupaten Pamekasan.

Secara keseluruhan, kesimpulan yang dapat diambil adalah bahwa baik pola bagi dua maupun pola bagi tiga belum sepenuhnya memberikan keadilan kepada petani penggarap sesuai dengan perjanjian atau kesepakatan antara kedua belah pihak. Nilai $\mu$ yang diperoleh telah menunjukkan bahwa berdasarkan analisis keuntungan, baik pemilik lahan maupun petani penggarap belum menerima keuntungan yang setimpal dengan korbanan yang telah dilakukannya. Salah satu penyebabnya adalah tingginya biaya pinjaman yang tentu memengaruhi tingkat keuntungan yang diterima oleh masingmasing pihak yang menjalankan sistem bagi hasil. Analisis keuntungan, analisis uji beda keuntungan, dan analisis perbandingan keuntungan merupakan bukti nyata bahwa memang terdapat ketidakadilan dalam sistem bagi hasil usaha garam rakyat di Kabupaten Pamekasan. Hal ini telah sesuai dengan beberapa kajian mengenai sistem bagi hasil, salah satunya adalah Nurdiani (2013), yang menyatakan bahwa memang terdapat perbedaan keuntungan antara pemilik lahan dan petani penggarap. Antara pola bagi dua dan pola bagi tiga, pola bagi dua lebih memberikan keadilan karena pemilik lahan dan petani penggarap menerima bagian atau keuntungan yang sama besar. Sama halnya dengan kesimpulan Zhao et al. (2003) dan Pi (2013) dalam penelitiannya bahwa pola bagi dua (50:50) hanya bersifat normatif. Terbukti, saat ditanyakan kepada pemilik lahan, pola bagi dua akan berubah menjadi pola bagi tiga saat lahan garam yang digunakan menjadi lebih produktif atau dalam kondisi yang baik. Tujuan utama adalah agar pemilik lahan menerima keuntungan yang lebih besar.

\section{KESIMPULAN DAN IMPLIKASI KEBIJAKAN}

\section{Kesimpulan}

Keuntungan yang diterima oleh pemilik lahan pada pola bagi dua dan pola bagi tiga lebih besar dari petani penggarap. Hal ini disebabkan adanya biaya atas pinjaman yang harus ditanggung oleh petani penggarap. Bagi pemilik lahan, biaya tersebut menjadi penerimaan. Hal inilah yang menjadi alasan mengapa petani penggarap menerima keuntungan yang lebih rendah.

Keuntungan yang diterima oleh petani penggarap dalam pola bagi dua dan pola bagi tiga berbeda secara nyata terhadap keuntungan yang diterima oleh pemilik lahan. Kesimpulan ini menunjukkan bahwa memang keuntungan rata-rata yang diterima petani penggarap berbeda secara nyata dengan keuntungan rata-rata yang diterima oleh pemilik lahan. Perbedaan keuntungan rata-rata bisa mencapai angka Rp. 2.384.124 per hektar per musim (untuk pola bagi dua) dan Rp. 15.712.512 per hektar per musim (untuk pola bagi tiga).

Berdasarkan analisis perbandingan keuntungan relatif, nilai pola bagi dua $\left(\mu_{2}\right)$ dan pola bagi tiga $\left(\mu_{3}\right)$ belum sesuai dengan yang diharapkan. Nilai $\mu_{2}$ yang diharapkan adalah $\mu_{2}=$ 1,00 . Nilai $\mu_{3}$ yang diharapkan adalah $\mu_{3}=0,50$. Nilai rata-rata $\mu_{2}$ yang diperoleh adalah sebesar 0,829 dan nilai rata-rata $\mu_{3}$ adalah sebesar 0,485 . Dua nilai tersebut mengindikasikan bahwa pola bagi dua dan pola bagi tiga belum memberikan keadilan kepada pemilik lahan dan petani penggarap.

Analisis keuntungan dalam sistem bagi hasil, analisis uji beda, dan analisis perbandingan keuntungan relatif menunjukkan bahwa terdapat ketidakadilan dalam sistem bagi hasil usaha garam rakyat di Kabupaten Pamekasan. Salah satu penyebabnya adalah tingginya biaya atas pinjaman yang memengaruhi langsung terhadap tingkat keuntungan yang diterima oleh petani penggarap dan pemilik lahan. Pola bagi dua dirasa lebih memberikan keadilan kepada petani penggarap. Namun, bagi pemilik lahan, pola bagi tiga lebih menguntungkan sehingga pola bagi dua akan diubah menjadi pola bagi tiga jika lahan garam berada dalam kondisi yang lebih produktif. Secara keseluruhan, pola bagi dua dan pola 
bagi tiga bukanlah sistem pertanian yang efisien dan berkeadilan, terlebih bagi petani penggarap. Namun, sistem pertanian ini sangatlah sulit untuk dihilangkan dalam kehidupan masyarakat pedesaan. Pola bagi dua dan pola bagi tiga memiliki kelebihan dan kekurangan masing-masing dalam implementasi di lapang. Sangat sulit untuk menentukan pola manakah yang lebih efisien dan berkeadilan karena tidak adanya standar baku yang jelas mengenai hal tersebut.

\section{Implikasi Kebijakan}

Besarnya keuntungan yang diterima oleh pemilik lahan dan petani penggarap dipengaruhioleh harga garam. Kesimpulan tersebut menunjukkan bahwa harga garam merupakan faktor penting dalam usaha garam. Oleh karena itu, pemerintah perlu mengawasi harga garam agar kebijakan pemerintah mengenai harga dasar garam dapat ditransmisikan hingga ke tingkat petani garam. Sampai saat ini, dalam praktek di lapang, informasi harga jual-beli garam hanya dikuasai oleh pihakpihak tertentu saja.

Besarnya biaya atas pinjaman memengaruhi besarnya keuntungan yang diterima oleh pemilik lahan dan petani penggarap. Biaya atas pinjaman yang tinggi mengakibatkan berkurangnya tingkat kesejahteraan petani penggarap. Hal ini dapat diatasi dengan memberikan subsidi kredit. Subsidi kredit dapat dilakukan dengan mengganti bantuan Program Pemberdayaan Usaha Garam Rakyat (PUGAR) yang awalnya dalam bentuk natura (peralatan fisik) menjadi bantuan tunai. Bantuan tunai harus dilakukan dengan skema yang jelas. Misalnya melibatkan lembaga keuangan formal, seperti Bank Pembangunan Daerah (BPD), sebagai pihak penyalur kredit. Dengan demikian, pihak swasta, pihak pemerintah, dan pihak masyarakat turut terlibat dalam kebijakan tersebut.

\section{UCAPAN TERIMA KASIH}

Ucapan terima kasih saya sampaikan kepada seluruh pihak yang terlibat dalam penyusunan artikel ini. Termasuk di dalamnya, kedua dosen pembimbing dan dewan redaksi Jurnal Sosial Ekonomi Kelautan dan Perikanan atas review yang diberikan. Akhir kata, semoga artikel ini bermanfaat, terlebih untuk para pembaca dan pemerintah dapat mengambil poin penting dalam memuat kebijakan yang lebih pro kepada petani garam.

\section{DAFTAR PUSTAKA}

Anggraini, G. 2015. Faktor-Faktor yang Memengaruhi Besarnya Pinjaman Modal dan Perbandingan Pendapatan Peternak Domba Pinjam dan Nonpinjam di Desa Petir, Kabupaten Bogor [Skripsi]. Bogor (ID): Institut Pertanian Bogor.

Asmarantaka, R. W. 2012. Pemasaran Agribisnis (Agrimarketing). Bogor (ID): Departemen Agribisnis FEM-IPB.

Azriani, Z. 2014. Aksessibilitas dan Partisipasi Industri Kecil dan Rumahtangga pada Sumber Pembiayaan dan Pengaruhnya Terhadap Kinerja Usaha dan Kesejahteraan Rumahtangga di Kabupaten Bogor Jawa Barat [Disertasi]. Bogor (ID): Institut Pertanian Bogor.

Bardhan, P. and A. Rudra. 1978. Interlinkage of Land, Labour and Credit Relations: An Analysis of Village Survey Data in East India. Economic and Political Weekly. 13(76/) : 367-384.

Basu, S. 1997. Why Institutional Credit Agencies Are Reluctant to Lend to The Rural Poor: A Theoritical Analysis of The Indian Rural Credit Market. World Development Journal. 25(2): 267-280.

Braverman, A. 1984. Capital Requirements, Screening, And Interlinked Sharecropping And Credit Contracts. Journal of Development Economic. 14(2) : 359-374.

Gupta, M. R. 1989. Credit and Share-Cropping: Comments on Braverman and Srinivasan. Journal of Development Economics. 31(2): 403-411.

Lole, U. R. 1995. Kajian Ekonomi Sistem Bagi Hasil pada Pola Gaduhan Penggemukan Sapi Potong di Kawasan Timor Barat [Tesis]. Bogor (ID): Institut Pertanian Bogor.

Marshall, A. 1920. The Principle of Economics: 8th ed. London (UK): Macmillan and Co.

Nurdiani, N. 2013. Pola Kemitraan Usaha Garam Rakyat (Studi Kasus: Kabupaten Sumenep, Madura, Jawa Timur) [Tesis]. Bogor (ID): Institut Pertanian Bogor.

Pi, J. 2013. A New Solution to The Puzzle of Fifty-Fifty Split in Sharecropping. Ekonomska istraživanja Economic Research. 26(2): 439-450.

Prihantini, C. I. 2015. Efisiensi Pemasaran Garam Rakyat di Desa Padelegan, Kecamatan Pademawu, Kabupaten Pamekasan, Madura, Jawa Timur [Skripsi]. Bogor (ID): Institut Pertanian Bogor.

Prihantini, C.I., Y. Syaukat dan A. Fariyanti. 2016. Analisis Pinjaman dan Biaya Pinjaman dalam Pola Bagi Hasil Usaha Garam Rakyat di Kabupaten Pamekasan, Jawa Timur. Jurnal Sosial Ekonomi Perikanan dan Kelautan. 12(1): 109-119.

Ray, T. 1999. Share Tenancy as Strategic Delegation. Journal of Development Economics. 58(1): 45-60. 
Roy, J. and K. Serfes. 2001. Intertemporal Discounting and Tenurial Contracts. Journal of Development Economics. 64(2): 417-436.

Rochwulaningsih, Y. 2013. Tata Niaga Garam Rakyat Dalam Kajian Struktural. Jurnal Sejarah Citra Lekha. 17(1) : 59-66.

Sekretariat Daerah [Sekdakab] Kabupaten Pamekasan. 2015. Pemetaan Potensi Garam Kabupaten Pamekasan. Pamekasan (ID): Sekdakab Pamekasan.

Sekretariat Daerah Kabupaten [Sekdakab] Pamekasan. 2016. Pointer Bupati Kabupaten Pamekasan. Pamekasan (ID): Sekdakab Pamekasan.

Scheltema, A.M.P.A. 1985. Bagi Hasil di Hindia Belanda. Jakarta (ID): Yayasan Obor Indonesia.

Soeharjo, A. dn D. Patong. 1973. Sendi-sendi Pokok Usaha tani. Bogor (ID): Institut Pertanian Bogor.

Soekartawi. 1986. IImu Usaha tani dan Penelitian untuk Pengembangan Petani Kecil. Jakarta (ID): Universitas Indonesia Press.
Sukesi. 2011. Analisis Perilaku Masyarakat Petani Garam Terhadap Hasil Usaha di Kota Pasuruan. Pasuruan (ID): Jurnal Mitra Ekonomi dan Manajemen Bisnis. 2(2): 225-244.

Zhao. H., W. Wu and X. Chen. 2006. What Factors Affect Small and Medium-sized Entreprise's Ability to Borrow from Bank: Evidence from Chengdu City, Capital of South-Western China's Sichuan Province. Business Institute Berlin at the FHW Berlin - Berlin School of Economics (Working Paper). 
Lampiran1. Hasil Uji Beda Rata-rata (Two Sample T-Test and Confidence Interval) dengan Menggunakan Program Aplikasi Minitab 11.0.

Appendix1. Two Sample T-test and Confidence Interval Using Application Program Minitab 11.0.

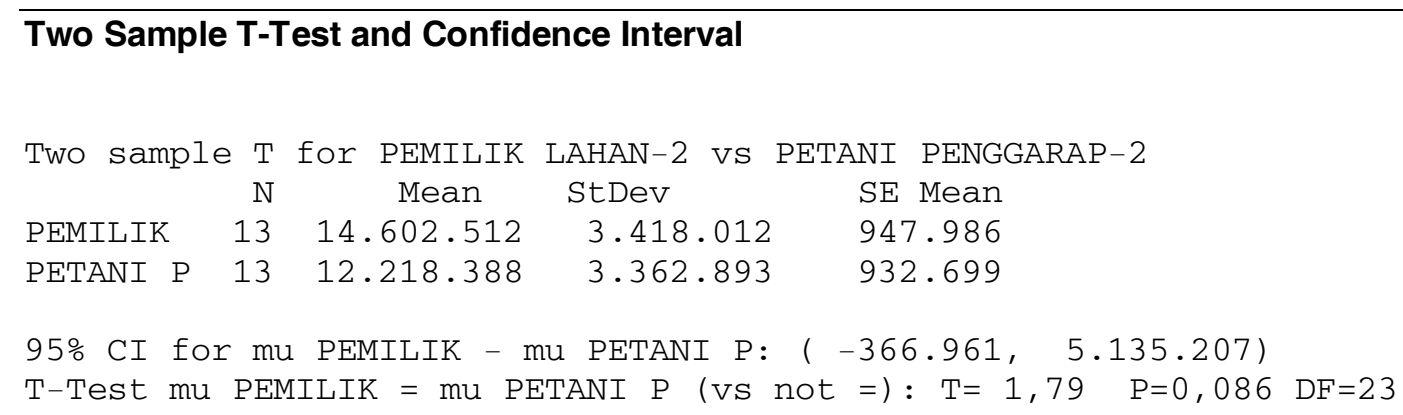

\section{Two Sample T-Test and Confidence Interval}

$\begin{array}{rrrrr}\text { Two sample } \mathrm{T} \text { for PEMILIK LAHAN-3 } & \text { Vs } & \text { PETANI PENGGARAP-3 } \\ \mathrm{N} & \text { Mean } & \text { StDev } & \text { SE Mean }\end{array}$

$\begin{array}{lllll}\text { PEMILIK } & 80 & 30.392 .865 & 15.791 .096 & 1.765 .498\end{array}$

PETANI P $80 \quad 14.680 .353 \quad 7.455 .856 \quad 833.590$

95\% CI for mu PEMILIK - mu PETANI P: ( $11.844 .087,19.580 .938)$

T-Test mu PEMILIK = mu PETANI $\mathrm{P}$ ( vs not =) : $\mathrm{T}=8,05 \mathrm{P}=0,0000 \mathrm{DF}=112$

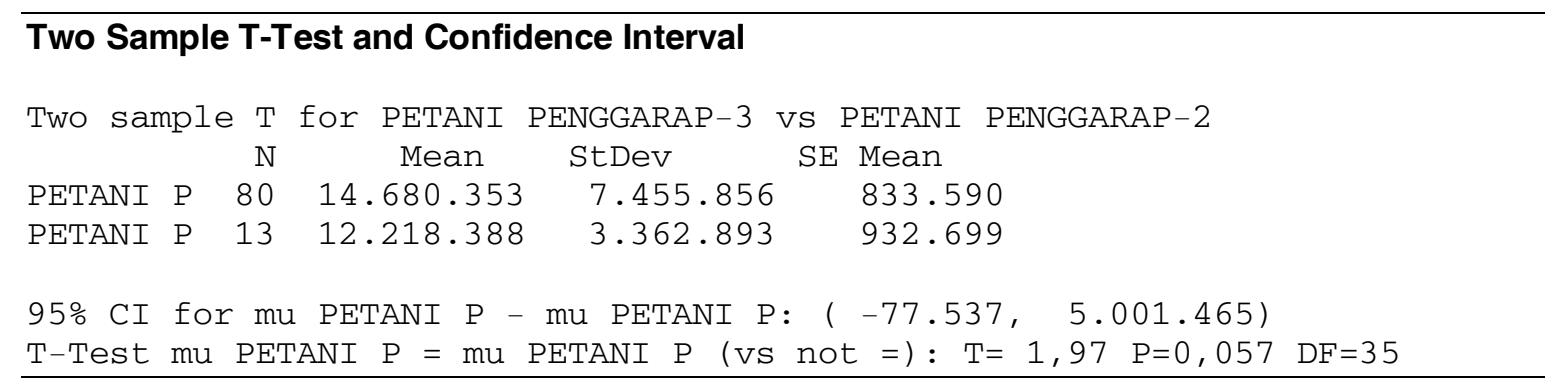

